\title{
The Effect of Islamic Work Ethic and Productivity on Work Quality Through The Employee Performance
}

\author{
Ahmad Hazas Syarif, ${ }^{1}$, Afida Rahmawati ${ }^{2}$, Muhammad Iqbal Fasa ${ }^{3}$
}

Raden Intan Islamic State University Lampung

E-mail: Hazassyarif@radenintan.ac.id, Afidarahmawati81@gmail.com, miqbalfasa@radenintan.ac.id

\begin{abstract}
The Islamic work ethic and productivity are parts of the work concept that raise value in forming good personality in the work based on the recommendation of the principle in Islam. The research investigated 40 employees as research samples through the utilization of quantitative methods: questionnaire (questionnaire), documentation, and observation. The used analysis included validity test, reliability test, statistical collinearity test, partial test, and determination test (R2). The tool in analyzing the data was path way analysis with the Smart Pls 3.0 program. The results found that the Islamic Work Ethic has a positive washback on Employee Performance, Work Quality, and Productivity. Employee Performance has a positive washback on employee performance with a positive and significant effect on work quality. Productivity does not significantly influence employee performance, and it also does not significantly influence work quality.
\end{abstract}

Keywords.

Islamic Work Ethic, Productivity, Work Quality, Employee Performance.

\section{INTRODUCTION}

Islam defines work as an obligation of every Muslim. Work is not just an effort for getting the halal sustenance to meet the necessities of life, but it implies the worship of a servant to Allah towards the success in the hereafter. Therefore, a Muslim makes work as his transcendent spiritual awareness (the religion of Allah). Muslim should always put the basis of expecting the pleasure from Allah in doing anything in their life. It implies that Muslim should not do anything in an arbitrary and indifferent manner. Moreover, the optimization of the work value is closely related to the concept of Ihsan. Ihsan is related to work ethic, which is doing the job as well as possible, as perfect as possible, or as optimal as possible. The designing and strengthening of the work ethic is not solely determined by the quality of education and achievement related to the profession and the work area, but it is also determined by factors that are closely related to the inner life, inner atmosphere, the spirit of life, which is rooted by faith. Therefore, religion become the source in finding the most righteous work ethic as the value system underlies all life activities. Thus, work is an embodiment and self-realization of their religion (Sirajuddin, 2016).

Productivity is very important for employees in a company. The successful and effective company or organization is the company or organization with individuals who have good performance. The effective or successful organization will be supported by the potential quality of human resources. Therefore, productivity must be a part that must not be forgotten in developing a business strategy, which covers the fields of production, marketing, finance and other fields. As for individuals, the factors that affect employee work productivity enable them to make more efforts for the escalation of their happiness in life. As for the industry, factors that influence employee work productivity are used as indicators of boosting the production and efforts in improving company cost efficiency by optimizing the role of labor in building a high work ethic and emphasizing changes in better workforce behavior (Rismayadi, 2015).

Each organization will basically implement different policies on its human resources in order to achieve employee productivity. Approaches in efforts to improve the quality of human resources could be utilizing psychological and organizational approaches, culture and religion (Prabowo, 2005). The concept of quality is relative matters, which does not always contain good meaning. Quality may be interpreted as the measurement that is embodied in a product or service. It shows the advantages possessed by the goods or services for costumer information and also the rightful liability (Flippo, 2005). 
The development of sharia economy in the world and also Indonesia which incidentally has a very high Muslim population is welcomed by financial service businesses by establishing Islamic banks. BMT EL-MENTARI "Darul Falah" branch of Seputih is a sharia-based savings and loan cooperative. Improving the quality of performance is a very important role in the Sharia savings and loan cooperative.

BMT has an Islamic foundation and philosophical foundation. The basis of sharia is the Qur'an and the hadith, while the philosophical foundation is monotheism, justice, balance, freedom, trustworthiness, responsibility, help, and support the burden. The the philosophical basis of is different from the bank. The foundation is intended to be an operational guideline for every account under the name of BMT (not a bank) to refer its philosophical foundation. The foundation also serves to distinguish BMT and other business ethics, both sharia and conventional, as well as distinguishing nonbank Islamic financial institutions and Islamic banks.

\section{LITERATURE REVIEW THEORETICAL FOUNDATION}

\section{Islamic Work Ethic}

Tasmara (2008) defines the Islamic work ethic is an earnest effort by mobilizing all of the assets, thoughts, and remembrance to actualize or reveal its meaning as a servant of Allah who subdues the world and places itself as part of the best society (khairul ummah). It could also be said that it is the work on humanizing human. Ethics as a rational critical reflection sees and reflects human life by taking themselves on moral norms and values, which exist on the one hand and the special situation of the field of life. The special activities define as the activity which is carried out by each person or group in a society. Ethics is beyond from looking at human behavior and life as human beings for granted, but rather seeing human behavior and life as humans in certain fields of life and specific activities. Yudiani (2016) shares three indicators of the Islamic work ethic the individual dimension, the social dimension, and the transcendental dimension.

\section{Productivity}

Work productivity is defined as the production of goods or service by individuals or groups during certain units of time in a work process. In this case, work productivity is described as how the workforce is able to complete the work by producing output in a relatively shorter time. In other words, productivity will be achieved when the production process requires a shorter time. The concept of productivity could be seen from two dimensions, namely the individual dimension and the organizational dimension. The study of productivity problems from the individual dimension is nothing but looking at productivity especially in relation to individual personality characteristics. In this context, the essence of the notion in productivity is a mental attitude that always has the view that the quality of life today must be better than yesterday, and tomorrow must be better than today (Rismayadi, 2015). Misbahudin (2016) states five indicators of productivity include ability, increasing the results achieved, morale, quality, and efficiency.

\section{Work Quality}

Work quality defines as the process in which an organization evaluates or evaluates work performance that is carried out properly, orderly, and correctly for increasing work motivation while increasing organizational loyalty of employees. It will certainly benefit the organization. At the very least, employees know the extent and measurement of the work quality and work performance. The work describes as the work quality shown by employees in order to provide the best performance for the organization. Meanwhile, Marcana in Rao states that the quality of work is a form of behavior or activities carried out in accordance with expectations and needs or goals achieved effectively and efficiently (Ceswirdani, Yuni \& Heni, 2017). Lestari (2015) shares the indicators of work quality include self-potential, work processes, optimal work results, and enthusiasm.

\section{Employee Performance}

Performance is the result of work that can be achieved by a person or group of people in an organization, which is related with their respective authorities and responsibilities. It aims to legally achieve the objectives of the organization concerned. It should not violate the law and in accordance with morals also ethics. It is also in line with what is explained by Bittel (1996), performance is a formal 
and systematic evaluation of how well a person is doing his job and fulfilling his appropriate role in the organization.

\section{PREVIOUS RESEARCHS}

The purpose of employee performance assessment of institutional and organizational is enroll as administrative and development step. Administratively, the Institution or organization could make an assessment of work performance as a reference or standard in making decisions regarding the conditions of employees including the promotion at higher career levels, termination, awards or payroll. Meanwhile, the development is a way to motivate and improve work skills, including providing counseling on employee behavior and following up with the provision of training (Gomez, 2001).

Cherrington (2000) adds other objectives, among others, to identify training needs for the benefit of employees in measuring the level of ability and expertise on a job may be increased at a higher level. Sudarmanto (2014) states that the indicators of employee include quality of work, quantity of work, use of time at work, and cooperation.

\section{RESEARCH METHODS}

\section{Research Type}

The research used quantitative approach. Quantitative method is a research method that can be interpreted as a research method based on the philosophy of positivism. It is used to examine specific populations or samples, collecting data using research instruments, analyzing quantitative data with the aim of testing existed hypotheses.

\section{Research Variables}

a. Independent variable (Islamic work ethic and productivity)

b. Dependent variable (work performance)

c. Mediated variable (employee performance)

\section{Population and Sample}

The population in the study was 40 employees from BMT EL-MENTARI "Darul Falah", the sample was 40 employees in which the researchers used a non probability sampling technique that is saturated sampling in which the entire population was sampled. For the population in the BMT EL-MENTARI "Darul Falah" as many as 40 employees and 40 employees for the sample where researchers used a non probability sampling technique that is saturated sampling in which the entire population was sampled.

\section{Data Collection Technique}

a. Observation

b. Question

c. Documentation

5. Data Analysis Technique

a. Method of analysis

b. Descriptive analysis

c. Validity test

d. Reliability test

e. Statistical collinearity test

f. t or partial test

g. Determination coefficient test

Path way analysis test 


\section{DISCUSSION}

Table 1

The Characteristic of Respondent based on Sex

\begin{tabular}{|l|l|l|}
\hline \multicolumn{1}{|c|}{ Sex } & \multicolumn{1}{c|}{ Number of Employee } & \multicolumn{1}{c|}{ Percentage } \\
\hline Male & 26 & $65 \%$ \\
\hline Female & 14 & $35 \%$ \\
\hline Total & 40 & $100 \%$ \\
\hline
\end{tabular}

Table 2

The Characteristic of Respondent based on Age

\begin{tabular}{|l|l|l|}
\hline \multicolumn{1}{|c|}{ Age } & \multicolumn{1}{c|}{ Number of Employee } & \multicolumn{1}{c|}{ Percentage } \\
\hline $20-29$ years old & 26 & $65 \%$ \\
\hline $30-39$ years old & 12 & $30 \%$ \\
\hline $40-49$ years old & 2 & $5 \%$ \\
\hline Total & 40 & $100 \%$ \\
\hline
\end{tabular}

Table 3

The Characteristic of Respondent based on Education Level

\begin{tabular}{|l|l|l|}
\hline \multicolumn{1}{|c|}{ Education Level } & \multicolumn{1}{c|}{ Number of Employee } & \multicolumn{1}{c|}{ Percentage } \\
\hline SHS & 28 & $70 \%$ \\
\hline D3 & 4 & $12.5 \%$ \\
\hline Bachelor Degree & 7 & $17.5 \%$ \\
\hline Total & 40 & $100 \%$ \\
\hline
\end{tabular}

Table 4

The Characteristic of Respondent based on Work Period

\begin{tabular}{|l|l|l|}
\hline \multicolumn{1}{|c|}{ Work Period } & \multicolumn{1}{c|}{ Number of Employee } & \multicolumn{1}{c|}{ Percentage } \\
\hline$<2$ tahun & 12 & $30 \%$ \\
\hline $3-5$ tahun & 12 & $30 \%$ \\
\hline$>5$ tahun & 16 & $40 \%$ \\
\hline Total & 40 & $100 \%$ \\
\hline
\end{tabular}

Table 5

The Response form Respondent on Islamic Work Ethic Variable

\begin{tabular}{|c|c|c|c|c|c|c|c|c|c|c|}
\hline \multirow{3}{*}{ Statement } & \multicolumn{10}{|c|}{ Number } \\
\hline & \multicolumn{2}{|c|}{$\begin{array}{l}\mathrm{SS} \\
(5) \\
\end{array}$} & & \multicolumn{2}{|c|}{$\begin{array}{l}N \\
(3)\end{array}$} & \multicolumn{2}{|c|}{$\begin{array}{l}\text { TS } \\
\text { (2) } \\
\end{array}$} & \multicolumn{2}{|c|}{$\begin{array}{l}\text { STS } \\
(1)\end{array}$} \\
\hline & $\mathrm{F}$ & $\%$ & $\mathrm{~F}$ & $\%$ & $\mathrm{~F}$ & $\%$ & $\mathrm{~F}$ & $\%$ & $\mathrm{~F}$ & $\%$ \\
\hline \multicolumn{11}{|c|}{ Individual Dimension } \\
\hline $\mathrm{X} 1.1$ & 24 & $60 \%$ & 16 & $40 \%$ & 0 & $0 \%$ & 0 & $0 \%$ & 0 & $0 \%$ \\
\hline $\mathrm{X} 1.2$ & 8 & $20 \%$ & 26 & $65 \%$ & 6 & $15 \%$ & 0 & $0 \%$ & 0 & $0 \%$ \\
\hline $\mathrm{X} 1.3$ & 5 & $12.5 \%$ & 24 & $60 \%$ & 11 & $27.5 \%$ & 0 & $0 \%$ & 0 & $0 \%$ \\
\hline $\mathrm{X} 1.4$ & 5 & $12.5 \%$ & 29 & $72.5 \%$ & 6 & $15 \%$ & 0 & $0 \%$ & 0 & $0 \%$ \\
\hline \multicolumn{11}{|c|}{ Social Dimension } \\
\hline $\mathrm{X} 1.5$ & 14 & $35 \%$ & 13 & $32.5 \%$ & 13 & $32.5 \%$ & 0 & $0 \%$ & 0 & $0 \%$ \\
\hline $\mathrm{X} 1.6$ & 7 & $17.5 \%$ & 22 & $55 \%$ & 11 & $27.5 \%$ & 0 & $0 \%$ & 0 & $0 \%$ \\
\hline $\mathrm{X} 1.7$ & 12 & $32.5 \%$ & 24 & $60 \%$ & 4 & $10 \%$ & 0 & $0 \%$ & 0 & $0 \%$ \\
\hline \multicolumn{11}{|c|}{ Tracentral Dimension } \\
\hline $\mathrm{X} 1.8$ & 17 & $42.5 \%$ & 18 & $45 \%$ & 5 & $12.5 \%$ & 0 & $0 \%$ & 0 & $0 \%$ \\
\hline $\mathrm{X} 1.9$ & 8 & $20 \%$ & 31 & $77.5 \%$ & 1 & $2.5 \%$ & 0 & $0 \%$ & 0 & $0 \%$ \\
\hline $\mathrm{X} 1.10$ & 7 & $17.5 \%$ & 21 & $52.5 \%$ & 12 & $30 \%$ & 0 & $0 \%$ & 0 & $0 \%$ \\
\hline
\end{tabular}


Table 6

The Response from Respondent on Productivity Variable

\begin{tabular}{|c|c|c|c|c|c|c|c|c|c|c|}
\hline \multirow{3}{*}{ Statement } & \multicolumn{10}{|c|}{ Number } \\
\hline & \multicolumn{2}{|c|}{$\begin{array}{l}\text { SS } \\
\text { (5) }\end{array}$} & \multicolumn{2}{|r|}{$\begin{array}{c}S \\
(4)\end{array}$} & \multicolumn{2}{|c|}{$\begin{array}{c}\mathrm{N} \\
(3)\end{array}$} & \multicolumn{2}{|c|}{$\begin{array}{l}\text { TS } \\
\text { (2) }\end{array}$} & \multicolumn{2}{|c|}{$\begin{array}{l}\text { STS } \\
\text { (1) }\end{array}$} \\
\hline & $\mathrm{F}$ & $\%$ & $\mathrm{~F}$ & $\%$ & $\mathrm{~F}$ & $\%$ & $\mathrm{~F}$ & $\%$ & $\mathrm{~F}$ & $\%$ \\
\hline \multicolumn{11}{|c|}{ Capability } \\
\hline $\mathrm{X} 2.1$ & 1 & $2.5 \%$ & 23 & $57.5 \%$ & 16 & $40 \%$ & 0 & $0 \%$ & 0 & $0 \%$ \\
\hline $\mathrm{X} 2.2$ & 8 & $20 \%$ & 26 & $65 \%$ & 6 & $15 \%$ & 0 & $0 \%$ & 0 & $0 \%$ \\
\hline \multicolumn{11}{|c|}{ Escalation on Achievement } \\
\hline $\mathrm{X} 2.3$ & 0 & $0 \%$ & 22 & $55 \%$ & 18 & $45 \%$ & 0 & $0 \%$ & 0 & $0 \%$ \\
\hline $\mathrm{X} 2.4$ & 16 & $40 \%$ & 23 & $57.5 \%$ & 1 & $2.5 \%$ & 0 & $0 \%$ & 0 & $0 \%$ \\
\hline \multicolumn{11}{|c|}{ Morale } \\
\hline $\mathrm{X} 2.5$ & 6 & $15 \%$ & 9 & $22.5 \%$ & 25 & $62.5 \%$ & 0 & $0 \%$ & 0 & $0 \%$ \\
\hline X2.6 & 15 & $37.5 \%$ & 18 & $45 \%$ & 7 & $17.5 \%$ & 0 & $0 \%$ & 0 & $0 \%$ \\
\hline \multicolumn{11}{|c|}{ Quality } \\
\hline X2.7 & 20 & $50 \%$ & 20 & $50 \%$ & 0 & $0 \%$ & 0 & $0 \%$ & 0 & $0 \%$ \\
\hline $\mathrm{X} 2.8$ & 11 & $27.5 \%$ & 21 & $52.5 \%$ & 8 & $20 \%$ & 0 & $0 \%$ & 0 & $0 \%$ \\
\hline X2.9 & 11 & $27.5 \%$ & 28 & $70 \%$ & 1 & $30 \%$ & 0 & $0 \%$ & 0 & $0 \%$ \\
\hline \multicolumn{11}{|c|}{ Efficiency } \\
\hline $\mathrm{X} 2.10$ & 20 & $50 \%$ & 20 & $50 \%$ & 0 & $0 \%$ & 0 & $0 \%$ & 0 & $0 \%$ \\
\hline
\end{tabular}

Table 7

The Response from Respondent on Work Quality

\begin{tabular}{|c|c|c|c|c|c|c|c|c|c|c|}
\hline \multirow{3}{*}{ Statement } & \multicolumn{10}{|c|}{ Number } \\
\hline & \multicolumn{2}{|r|}{$\begin{array}{l}\text { SS } \\
\text { (5) }\end{array}$} & \multicolumn{2}{|r|}{$\begin{array}{c}S \\
(4)\end{array}$} & \multicolumn{2}{|c|}{$\begin{array}{c}\mathrm{N} \\
\text { (3) }\end{array}$} & \multicolumn{2}{|c|}{$\begin{array}{l}\text { TS } \\
\text { (2) }\end{array}$} & \multicolumn{2}{|c|}{$\begin{array}{l}\text { STS } \\
(1)\end{array}$} \\
\hline & $\mathrm{F}$ & $\%$ & $\mathrm{~F}$ & $\%$ & $\mathrm{~F}$ & $\%$ & $\mathrm{~F}$ & $\%$ & $\mathrm{~F}$ & $\%$ \\
\hline \multicolumn{11}{|c|}{ Self-potential } \\
\hline Y.1 & 16 & $40 \%$ & 24 & $60 \%$ & 0 & $0 \%$ & 0 & $0 \%$ & 0 & $0 \%$ \\
\hline Y.2 & 8 & $20 \%$ & 26 & $65 \%$ & 6 & $15 \%$ & 0 & $0 \%$ & 0 & $0 \%$ \\
\hline Y.3 & 5 & $12.5 \%$ & 24 & $60 \%$ & 11 & $27.5 \%$ & 0 & $0 \%$ & 0 & $0 \%$ \\
\hline Y.4 & 5 & $12.5 \%$ & 30 & $75 \%$ & 5 & $12.5 \%$ & 0 & $0 \%$ & 0 & $0 \%$ \\
\hline \multicolumn{11}{|c|}{ Work Process } \\
\hline Y.5 & 7 & $17.5 \%$ & 21 & $52.5 \%$ & 12 & $30 \%$ & 0 & $0 \%$ & 0 & $0 \%$ \\
\hline Y.6 & 3 & $7.5 \%$ & 27 & $67.5 \%$ & 10 & $25 \%$ & 0 & $0 \%$ & 0 & $0 \%$ \\
\hline \multicolumn{11}{|c|}{ Optimal Work Result } \\
\hline Y.7 & 6 & $15 \%$ & 18 & $45 \%$ & 16 & $40 \%$ & 0 & $0 \%$ & 0 & $0 \%$ \\
\hline Y.8 & 7 & $17.5 \%$ & 20 & $50 \%$ & 13 & $32.5 \%$ & 0 & $0 \%$ & 0 & $0 \%$ \\
\hline \multicolumn{11}{|c|}{ Enthusiasm } \\
\hline Y.9 & 8 & $20 \%$ & 31 & $77.5 \%$ & 1 & $2.5 \%$ & 0 & $0 \%$ & 0 & $0 \%$ \\
\hline Y.10 & 20 & $50 \%$ & 20 & $50 \%$ & 0 & $0 \%$ & 0 & $0 \%$ & 0 & $0 \%$ \\
\hline
\end{tabular}


Table 8

The Response of Respondent on Employee Performance Variable

\begin{tabular}{|c|c|c|c|c|c|c|c|c|c|c|}
\hline \multirow{3}{*}{ Statement } & \multicolumn{10}{|c|}{ Number } \\
\hline & \multicolumn{2}{|c|}{$\begin{array}{l}\text { SS } \\
\text { (5) }\end{array}$} & \multicolumn{2}{|r|}{$\begin{array}{c}S \\
(4)\end{array}$} & \multicolumn{2}{|c|}{$\begin{array}{c}\mathrm{N} \\
\text { (3) }\end{array}$} & \multicolumn{2}{|c|}{$\begin{array}{l}\mathrm{TS} \\
\text { (2) }\end{array}$} & \multicolumn{2}{|c|}{$\begin{array}{c}\text { STS } \\
(1)\end{array}$} \\
\hline & $\mathrm{F}$ & $\%$ & $\mathrm{~F}$ & $\%$ & $\mathrm{~F}$ & $\%$ & $\mathrm{~F}$ & $\%$ & $\mathrm{~F}$ & $\%$ \\
\hline \multicolumn{11}{|c|}{ Work Quality } \\
\hline M.1 & 25 & $62.5 \%$ & 15 & $37.5 \%$ & 0 & $0 \%$ & 0 & $0 \%$ & 0 & $0 \%$ \\
\hline M.2 & 4 & $10 \%$ & 24 & $60 \%$ & 12 & $30 \%$ & 0 & $0 \%$ & 0 & $0 \%$ \\
\hline M.3 & 30 & $75 \%$ & 5 & $12.5 \%$ & 5 & $12.5 \%$ & 0 & $0 \%$ & 0 & $0 \%$ \\
\hline \multicolumn{11}{|c|}{ Work Quantity } \\
\hline M.4 & 0 & $0 \%$ & 12 & $30 \%$ & 17 & $42.5 \%$ & 11 & $27.5 \%$ & 0 & $0 \%$ \\
\hline M.5 & 1 & $2.5 \%$ & 27 & $67.5 \%$ & 12 & $30 \%$ & 0 & $0 \%$ & 0 & $0 \%$ \\
\hline \multicolumn{11}{|c|}{ Work Estimation on Work } \\
\hline M.6 & 16 & $40 \%$ & 22 & $55 \%$ & 2 & $5 \%$ & 0 & $0 \%$ & 0 & $0 \%$ \\
\hline M.7 & 12 & $30 \%$ & 28 & $70 \%$ & 0 & $0 \%$ & 0 & $0 \%$ & 0 & $0 \%$ \\
\hline \multicolumn{11}{|c|}{ Team Work } \\
\hline M.8 & 19 & $47.5 \%$ & 19 & $47.5 \%$ & 2 & $5 \%$ & 0 & $0 \%$ & 0 & $0 \%$ \\
\hline M.9 & 8 & $20 \%$ & 29 & $72.5 \%$ & 1 & $2.5 \%$ & 0 & $0 \%$ & 0 & $0 \%$ \\
\hline M.10 & 8 & $20 \%$ & 26 & $65 \%$ & 6 & $15 \%$ & 0 & $0 \%$ & 0 & $0 \%$ \\
\hline
\end{tabular}

\section{The Result on Validity Test}

SmartPLS 3 is used in measuring the level of validity through the computerized method with testing techniques using the Pearson correlation formula.

\section{The Result of Reliability Test}

Based on the results of the reliability test from the questionnaire, the questionnaire is stated to be reliable as more than 0.60 . The details may be depicted in Table 9 .

\section{Table 9}

\section{Reliability Test}

\begin{tabular}{|l|l|l|}
\hline \multicolumn{1}{|c|}{ Variable } & \multicolumn{1}{c|}{ Cronbach alpa } & \multicolumn{1}{c|}{ Information } \\
\hline Islamic Work Ethic (X1) & 0.733 & Reliable \\
\hline Productivity (X2) & 0.728 & Reliable \\
\hline Work Quality (Y) & 0.761 & Reliable \\
\hline Employee Performance (M) & 0.801 & Reliable \\
\hline
\end{tabular}

\section{The Test of Collinearity Statistics (VIF)}

Collinearity Statistics in a regression would interfere with the results of the research regression. Thus, it does not produce efficient and effective parameters that would encounter errors in the produced parameters.

Figure 1. The Result of The Collinearity Statistics Test (VIF)

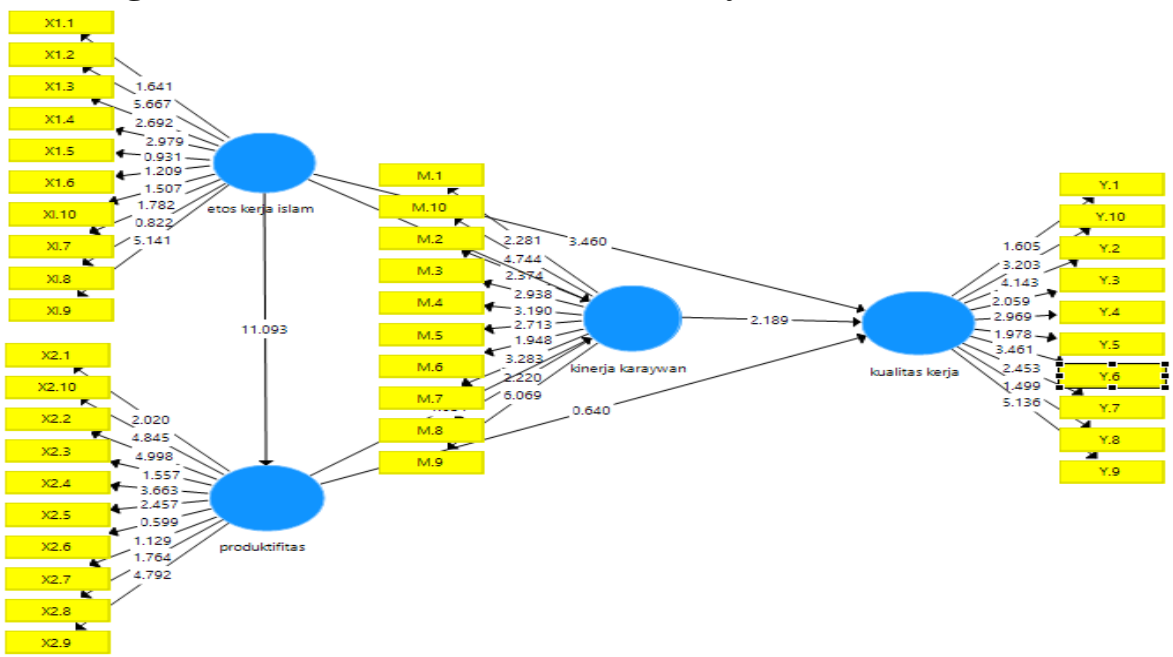




\section{The Hypotheses Testing}

\section{a. The Test of Determination Coefficient $\left(\mathbf{R}^{2}\right)$}

Determination Coefficient is generally used in measuring the level of independent variable capability in influencing the dependent variable.

\section{Table 10}

The Test of Determination Coefficient

\begin{tabular}{|l|l|l|}
\hline \multicolumn{1}{|c|}{ Variable } & R Square Adjusted & R Square \\
\hline Work Quality & 0.742 & 0.755 \\
\hline Employee Performance & 0.859 & 0.870 \\
\hline Productivity & 0.577 & 0.588 \\
\hline
\end{tabular}

\section{b. The Test of $T$ or the Partial Test}

$\mathrm{T}$ test is used to test the partial effect of independent variables on the dependent variable. In this study, it describes as the effect Islamic work ethic and productivity on work quality through employee performance, which is stated as the dependent variable. The test criteria states that if the probability value $<\alpha$, then it is stated the influence of the independent variable has partial effect on the dependent variable. The result of testing the variables could be seen in the Table 11.

\section{Table 11}

The Test of Partial Significance

\begin{tabular}{|l|l|l|}
\hline \multicolumn{1}{|c|}{ The Effect on Variable } & T Statistics & \multicolumn{1}{c|}{ Probability } \\
\hline Islamic Work Ethic $\rightarrow$ Employee Performance & 4.874 & 0.000 \\
\hline Islamic Work Ethic $\rightarrow$ Work Quality & 3.460 & 0.001 \\
\hline Islamic Work Ethic $\rightarrow$ Productivity & 11.093 & 0.000 \\
\hline Employee Performance $\rightarrow$ Work Quality & 2.189 & 0.029 \\
\hline Productivity $\rightarrow$ Employee Performance & 1.651 & 0.099 \\
\hline Productivity $\rightarrow$ Work Quality & 0.640 & 0.522 \\
\hline
\end{tabular}

Hypothesis 1, Islamic work ethic on employee performance shows a statistical T value of 4.874 with the probability of 0.000 . The test result shows that probability > alpha (5\%). It means that there is a significant direct effect of the Islamic work ethic on employee performance. Thus, the $\mathrm{H}_{0}$ is rejected.

Hypothesis 2, the Islamic work ethic on work quality states a statistical T value of 3,460 with the probability of 0.001 . The test result shows that the probability < alpha (5\%). It means that there is a significant direct effect from the Islamic work ethic on work quality. Thus, $\mathrm{H}_{0}$ is rejected.

Hypothesis 3, the Islamic work ethic of productivity shows a statistical T value of 11,093 with the probability of 0,000 . The test result shows that the probability < alpha $(5 \%)$. It means that there is a significant direct effect from the Islamic work ethic on productivity. Thus, $\mathrm{H}_{0}$ is rejected.

Hypothesis 4, employee performance on work quality produces a statistical T value of 2.189 with a probability of 0.029 . The test result shows that the probability <alpha (5\%). It means that there is a significant direct effect of employee performance on work quality. Thus, $\mathrm{H}_{0}$ is rejected.

Hypothesis 5, productivity on employee performance results a statistical $\mathrm{T}$ value of 1.651 with the probability of 0.099 . The test result shows that probability > alpha $(5 \%)$. It means that there is no significant direct effect from productivity on employee performance. Thus, $\mathrm{H}_{0}$ is accepted.

Hypothesis 6, productivity on work quality shows a statistical T value of 0.640 with a probability of 0.522 . The test result shows that probability > alpha $(5 \%)$. It means that there is no significant direct effect of productivity on work quality. Thus, $\mathrm{H}_{0}$ is accepted.

\section{c. The Result of Path Way Analysis}

The conversion of path diagrams into measurement models is intended to transform the diagram model into a measurement model based on empirical data that is used to determine the effect of independent variables on the dependent variable, whether the effect is direct or indirect. Figure 2 depicts the path analysis results. 
The Result of Path Way Analysis

Figure 2

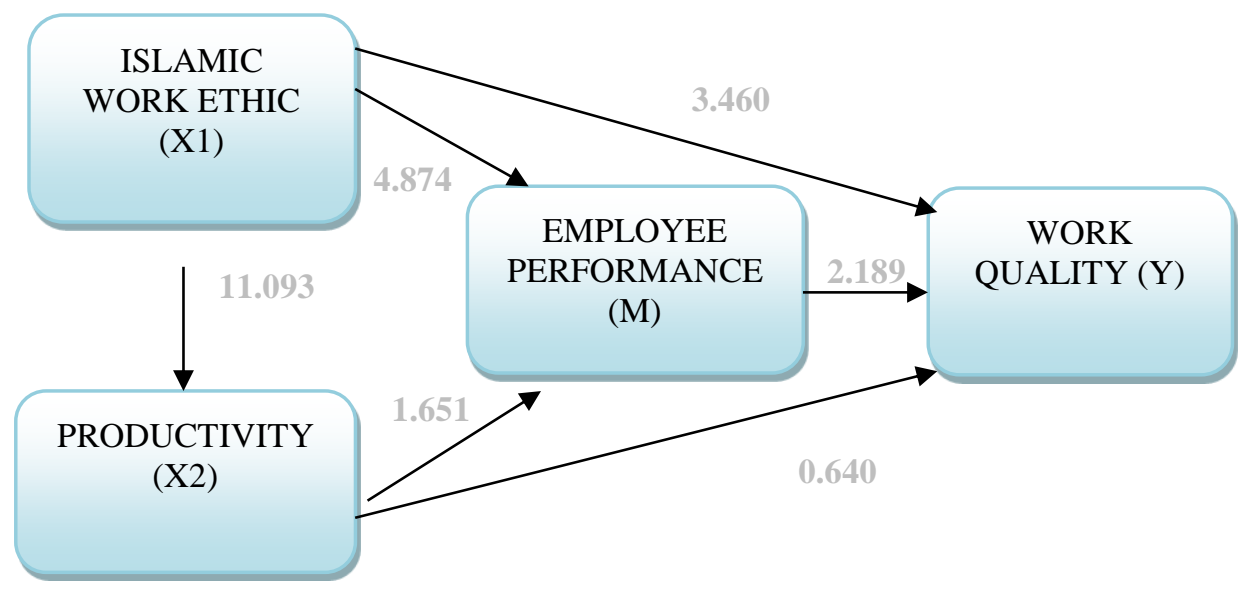

Table 12

Path Analysis

\begin{tabular}{|l|l|l|l|l|}
\hline \multirow{2}{*}{\multicolumn{1}{c|}{ Independent }} & \multirow{2}{*}{ Dependent } & \multicolumn{3}{c|}{ Coefficient } \\
\cline { 3 - 5 } & & Direct & Indirect & Total \\
\hline Islamic Work Ethic & Employee Performance & 4.874 & 1.548 & 6.422 \\
\hline Islamic Work Ethic & Work Quality & 3.560 & 2.704 & 6.264 \\
\hline Islamic Work Ethic & Productivity & 11.093 & - & 11.093 \\
\hline Employee Performance & Work Quality & 2.189 & - & 2.189 \\
\hline Productivity & Employee Performance & 1.651 & - & 1.651 \\
\hline Productivity & Work Quality & 0.640 & 1.180 & 1.820 \\
\hline
\end{tabular}

Source: Analyzed Data in 2019

Based on Table 12, some information could be retrieved.

a) Direct Effect

1) The coefficient of direct influence from the Islamic work ethic to the employee performance shows value of 4.874. It means that the Islamic work ethic has a positive and significant effect on performance. Thus, the better of Islamic work ethic, performance would be improved.

2) The coefficient of direct influence from the Islamic work ethic to the quality of work results 3.560. It means that the Islamic work ethic has a positive and significant impact on the quality of employee work. Thus, the better Islamic work ethic, the quality of work would be escalated.

3) The coefficient of direct influence of the Islamic work ethic on productivity by 11.093 shows that the Islamic work ethic has a positive and significant effect on productivity. Thus, the better the Islamic work ethic, the tendency can increase productivity.

4) The coefficient of direct influence from employee performance to the work quality shows number of 2.189. It shows that employee performance has a positive and significant effect on employee work quality. Thus, the better of employee performance, it tends to improve the quality of work.

5) The coefficient of direct influence on productivity on employee performance is 1.651 . it shows that productivity has a positive but not significant effect on employee performance. Thus, the better productivity tends to improve employee performance, but the escalation is not significant.

6) The coefficient of direct influence from productivity on work quality is 0.640 . It shows that productivity has a positive but not significant effect on work quality. Thus, the better productivity tends to improve the quality of work, but the escalation is not significant.

b) Indirect Effect

1) The effect of Islamic work ethic variable on work quality through employee performance is depicted by $(\mathrm{X} 1 \quad \mathrm{M} \quad \mathrm{Y})=(4.874+1.548)=6.422$. The indirect effect from Islamic work ethic on work quality with the mediation of employee $\overrightarrow{p e r f o r m a n c e}$ reach the number of 6.422 . 
The effect of productivity variable on work quality through employee performance is depicted by $\left(\begin{array}{lll}\mathrm{X} 2 & \mathrm{M} & \mathrm{Y}\end{array}\right)=(0.640+1.180)=1.820$. The indirect effect of productivity on work quality with the mediation of employee performance reach the number of 1.820 .

\section{CLOSING}

\section{Conclusions}

The conclusions from the results of the study under the title of The Influence of the Work Ethic and Productivity on Work Quality through Employee Performance (Study at BMT EL-MENTARI "Darul Falah" Branch of Seputih Banyak, Lampung Tengah) are as follows:

1) Based on the results of the partial test, Islamic work ethic has a positive and significant effect on employee performance at BMT EL-MENTARI "Darul Falah". The T value reached 4.874 with a probability of 0.000 .

2) Based on the results of a partial test, productivity does not affect the performance of employees at BMT EL-MENTARI "Darul Falah". The T value showed number of 1.651 with a probability of 0.009 .

3) Based on the partial test results, the Islamic work ethic has a positive and significant effect on the work quality at BMT EL-MENTARI "Darul Falah". The T value reached 3.460 with a probability of 0.001 .

4) Based on the indirect effect, the direct influence of Islamic work ethic on work quality shows greater number than the indirect effect of Islamic work ethic on work quality.

5) Based on the partial test results, productivity did not affect the work quality at BMT EL MENTARI "Darul Falah". The T value shows 0.640 with a probability of 0.522 .

6) Based on the indirect effect, the direct effect of productivity to the work quality showed lower result than the indirect effect of productivity to the work quality.

7) Based on the partial test results, employee performance had a positive and significant effect on work quality at BMT EL-MENTARI "Darul Falah". The T value reached 2.189 with a probability of 0.029 .

8) Based on the results of a partial test, the Islamic work ethic had a positive and significant effect on productivity at BMT EL-MENTARI "Darul Falah". The T value showed 11.093 with a probability of 0.000 .

\section{Suggestions}

Firstly, the suggestion from this study that the stakeholders of the BMT should enhance the knowledge of employee regarding the islamic work ethic because this can incline the work quality every labor in the BMT foundation.

Secondly, this study has not finish yet because there are several hypothesises that has not been answered yet, hence in the next other research regarding this is that the researcher must include other variables that are related from this research to increase the effect of the productivity at BMT.

\section{REFERENCES}

Bittel, R. Lester, dan John W. Newstrom, 1996. Pedoman bagi Supervisor. Terjemahan, Jakarta: Pustaka Binaman Pressindo.

Ceswirdani, Henny Sjafitri, dan Yuni Candra, Pengaruh Kompetensi Dan Kualitas Kerja Terhadap Prestasi Kerja Pegawai Di Kantor Kecamatan Kuranji, Jurnal Manajemen dan Kewirausahaan, Vol. 8, No. 1, Januari 2017, 1-15.

Cherrington, J. David, 2000. The Management of Human Resource, New Jersey: Prentice Hall International, Inc.

Flippo, Edwin B, Manajemen Personalia Edisi Keenam, Jakarta: Raja Bandung, 2005.

Gomez-Mejia, R. Luis, dkk., 2001 Managing Human Resources. New Jersey: Prentice Hall. 
Lestari, Puput Wahyu, Pengaruh Kualitas Kerja Pegawai Terhadap Kualitas Pelayanan Publik Di Kantor Pelayanan Pajak Daerah Provinsi Kepulauan Riau Samsat Tanjungpinang, Naskah Publikasi, Fakultas Ilmu Sosial dan Politik Universitas Maritim Raja Ali Haji, 2015.

Muayyad, Deden Misbahudin dan Ade Irma Oktafia Gawi,Pengaruh Kepuasan Kerja Terhadap Produktivitas KerjaPegawai Bank Syariah X Kantor Wilayah Ii, Jurnal Manajemen dan Pemasaran Jasa, Vol . 9, No. 1, 2016, 75-98.

Prabowo, Anwar Mangkunegara, Evaluasi Kinerja, Bandung: PT Refika Aditama, 2005.

Rismayadi, Budi, Faktor-Faktor Yang Mempengaruhi Produktivitas Karyawan: Studi Kasus Pada CV Mitra Bersama Lestari Tahun 2014,Jurnal Manajemen \& Bisnis, Vol, 1 No, 1, 2015, 1-16.

Sirajuddin, Betri,Pengaruh Etika Kerja Islam Terhadap Komitmen Profesi Internal Auditor, Komitmen Organisasi dan Sikap Perubahan Organisasi Pada Perbankan Syariah Di Kota Palembang,IEconomic, Vol. 2, No. 2, 2016.

Sudarmanto, Kinerja Dan Pengembangan Kompetensi SDM, Yogyakarta: Pustaka Pelajar, 2014.

Tasmara, Toto, Membudayakan Etos Kerja Islam, Cet.Ke-5, Jakarta: Gema Isnani, 2008.

Yudiani, Ema, Etos Kerja Islami Dosen Fakultas Ushuluddin Dan Pemikiran Islam Uin Raden Fatah Palembang Ditinjau Dari Religiusitas, PSIKIS-Jurnal Psikologis Islami, Vol. 2, No. 1, 2016, 1 15. 